\title{
Evaluation of Antiangiogenic and Antimetastatic Effects of Penicillium chrysogenum Secondary Metabolites
}

\author{
M. DIKMEN ${ }^{1 *}$, Z. CANTÜRK² , E. KAYA TILKI AND S. ENGÜR ${ }^{3}$ \\ Department of Pharmacology, Faculty of Pharmacy, ${ }^{1}$ Clinical Pharmacy Eskişehir, ${ }^{2}$ Deparment of Pharmaceutical \\ Microbiology, Faculty of Pharmacy, ${ }^{3}$ Graduate School of Health Sciences, Anadolu University, Eskişehir-26470, Turkey
}

Dikmen, et al.: Antiangiogenic and Antimetastatic Effects of Penicillium chrysogenum

\begin{abstract}
Development of resistance to standard therapy and toxic side effects are the major challenges encountered in chemotherapy of colorectal cancer. Increasing evidence has shown the ability of natural products to overcome various challenging disorders. Since, the development of antibiotics, fungi have been shown to be a wide useful source of lead compounds for the development of new pharmaceuticals. Fungal secondary metabolites from extreme environments are remarkable due to their diverse components, which makes them interesting candidates for drug discovery. In order to discover novel active antimetastatic and antiangiogenic compounds, secondary metabolites of halotolerant Penicillium chrysogenum-1 isolated from Tuz Lake in Turkey and ethyl acetate extract of halotolerant $P$. chrysogenum-1 was prepared from the isolate of halotolerant $P$. chrysogenum-1 culture medium. Firstly, antioxidant activity of the extract was determined. Then cytotoxicity and cell proliferation were investigated by WST-1 assay and real-time cell analysis system-DP on human umbilical vein endothelial cells and colorectal carcinoma cells, respectively. Antiangiogenic effects on human umbilical vein endothelial cells were evaluated with cell migration and invasion assays by using real-time cell analysis system. Also, mRNA expression levels of metastasis and angiogenesis-related genes, VEGFA, VEGFB, EGFR, COX-10, ANGPT-1 and IL-8 were determined on both cell lines. Results indicated that halotolerant $P$. chrysogenum-1 extract exhibited significant antimetastatic and antiangiogenic effects. According to the real-time cell analysis system results, $\mathrm{IC}_{50}$ concentrations of halotolerant $P$. chrysogenum-1 extract on Caco-2 and human umbilical vein endothelial cells were calculated as 55.2 and $37.89 \mu \mathrm{g} / \mathrm{ml}$, respectively for $72 \mathrm{~h}$. These results indicated that the secondary metabolites of halotolerant $P$. chrysogenum-1 extract could have the potential as a preventive and therapeutic agent in metastatic cancer processes.
\end{abstract}

Key words: Halotolerant, antiangiogenesis, antimetastatic, Penicillium chrysogenum

Colorectal cancer (CRC) is the third most prevalent cancer in the world. The main treatment strategies, including 5-fluorouracil, new angiogenesis inhibitors, and epidermal growth factor receptor (EGFR) inhibitors, result with poor response in most advanced stages and are usually followed by other tissue damages ${ }^{[1]}$. Angiogenesis is the sprouting of new blood vessels from pre-existing vessels and is strongly involved in solid tumour formation because it is essential for growth and metastasis of malignant tumours. Tumour angiogenesis is the consequence of an angiogenic imbalance in which proangiogenic factors prevail antiangiogenic factors ${ }^{[2]}$.

Despite the fact that chemotherapy is fundamental to the clinical management of cancer, failure in chemotherapy is not uncommon, mainly due to the dose-limiting toxicities and provoking severe adverse reactions in human beings. In spite of the extensive

*Address for correspondence E-mail: mirisd@anadolu.edu.tr

January-February 2017 progress in chemotherapy over the last decade, there is still a need for discovery and development of alternative or adjuvant therapeutic agents. In the realm of drug discovery, natural products provide a vast pool for screening for new antiangiogenic and antitumor agents including candidate compounds to overcome cancer and also low-toxic anticancer agents from fungi has become one of the research subjects in the current pharmacy field ${ }^{[3,4]}$.

In recent years, fungi from extreme environments have attracted considerable attention. Salt lakes and solar salterns are unique hyper saline environments,

This is an open access article distributed under the terms of the Creative Commons Attribution-NonCommercial-ShareAlike 3.0 License, which allows others to remix, tweak, and build upon the work non-commercially, as long as the author is credited and the new creations are licensed under the identical terms

Accepted 04 January 2017

Revised 02 November 2016

Received 28 June 2016

Indian J Pharm Sci 2017;79(1): 49-57 
characterized by their high salt concentration and alkaline $\mathrm{pH}^{[5]}$. Tuz Lake is an inland hyper saline water body (salinity above $30 \% \mathrm{NaCl}$ ) and is the second largest lake of Turkey with a length of $90 \mathrm{~km}$, a width of $35 \mathrm{~km}$ and a total surface of $1665 \mathrm{~km}^{2}$ within a closed basin, which is located in the Central Anatolia Region, Konya ${ }^{[6]}$. Hyper saline environments have been considered to be populated almost completely by prokaryotic organisms for a long time and fungi that can survive in environments with low water activity were discovered recently. Fungal secondary metabolites from extreme environments are remarkable due to their diverse components, which makes them interesting candidates for drug discovery.

In this study, antimetastatic and antiangiogenic effects of the secondary metabolites of halotolerant Penicillium chrysogenum isolated from Tuz Lake were investigated with various pharmacological methods. Thus, we aimed to bring different perspective for fungi secondary metabolites, an excellent potential source of new natural products, isolated from extreme environments.

\section{MATERIALS AND METHODS}

\section{Microorganism culture conditions and preparation of ethyl acetate extraction:}

Halotolerant P. chrysogenum-1 (HP-1) was isolated from one of the biggest lakes in Turkey, Tuz Lake, located in the Central Anatolia Region. The stock culture of HP-1 was grown on the slant of malt extract agar (MEA) and maintained at $25^{\circ}$ in an incubator. The isolates were incubated in static conditions in an antioxidant liquid medium at $27^{\circ}$ for $7 \mathrm{~d}$. After the incubation period, the isolates were filtered with Whatman no. 1 paper to be separated from micelles. Collected supernatant was extracted with ethyl acetate at 1:1 rate for 3 times. The organic phase was intensified by evaporating in rotavapor (Heidolph, Germany). Also, identification of HP-1 was conducted with classical methods earlier ${ }^{[7]}$. Antioxidant activity was determined higher than positive control butylated hydroxytoluene (BHT). Fungal ethyl acetate extract was dissolved in dimethyl sulfoxide (DMSO) and diluted to working concentrations with fresh medium. Control group (solvent control) was prepared with medium containing $0.1 \%$ DMSO.

\section{Cell culture:}

Human umbilical vein endothelial cells (HUVECs, ATCC number CRL-130TM) and human CRC (Caco-
2, ATCC number HTB-37 ${ }^{\mathrm{TM}}$ ) cells were obtained from American Type Culture Collection (ATCC). HUVECs were cultured in $2 \mathrm{mM}$ L-glutamine, $0.1 \mathrm{mg} / \mathrm{ml}$ heparin, $1.5 \mathrm{~g} / 1 \mathrm{NaHCO}_{3}$ (sodium bicarbonate), $0.03 \mathrm{mg} / \mathrm{ml}$ endothelial cell growth factor and 10\% FBS containing F12K medium. Caco-2 cells were grown in RPMI 1640 medium supplemented with $2 \mathrm{mM}$ L-glutamine, $10 \%$ foetal bovine serum and $1 \%$ penicillin/streptomycin at $37^{\circ}$ in a humidified incubator with $5 \% \mathrm{CO}_{2}$.

\section{WST-1 cytotoxicity assay:}

Cytotoxicity was measured using a colorimetric assay for 96-well plates with 2-(4-iodophenyl)-3-(4nitrophenyl)-5-(2,4-disulfophenyl)-2H-tetrazolium monosodium salt, the WST-1 assay. In this method, the reduced tetrazolium salt was water soluble ${ }^{[8]}$. HUVEC and Caco-2 cells were seeded in 96-well plates at a density of $5 \times 10^{3}$ cells per well. After $24 \mathrm{~h}$, different HP-1 concentrations $(25,50,100,200$ and $400 \mu \mathrm{g} /$ $\mathrm{ml}$ for HUVEC; 50, 100, 150, 200, 300 and $400 \mu \mathrm{g} /$ $\mathrm{ml}$ for Caco-2 cells) were added to wells. Plates were incubated for 24 or $48 \mathrm{~h}$. After incubation periods, $10 \mu \mathrm{l}$ WST-1 solutions were added to each well and incubated for $3 \mathrm{~h}$. The absorbance was measured at $420 \mathrm{~nm}$ using a cytation 3 cell 1maging multi-mode reader (Bio-Tek) according to the WST-1 kit protocol (Cat. no:11644807001, Roche). Cell survival rates were expressed as the percentage of the DMSO $(0.1 \%)$ solvent control. The measured absorbance directly correlates with the number of viable cells.

\section{Cell proliferation assay with real-time cell analysis system (RTCA DP):}

Kinetics of cell proliferation were monitored with xCELLigence RTCA DP instrument, which measures electrical impedance across interdigitated microelectrodes incorporated on the bottom of tissue culture E-Plates. Electrical impedance indicated as cell index (CI) value and provides quantitative information about the condition of the cells, involving cell number, viability, and morphology ${ }^{[9]}$.

Background of the E-plates (16 well) were measured in $100 \mu 1$ medium in the RTCA DP station. Afterwards $100 \mu 1$ of a HUVEC and Caco-2 cell suspensions was added (20 000 cells/well). Plates were incubated for $30 \mathrm{~min}$ at room temperature and E-plates were placed into the instrument and impedance was measured at 1 $\mathrm{h}$ intervals. Approximately $20 \mathrm{~h}$ after seeding, when the cells were in the log growth phase, the instrument was paused and the cells were treated with $100 \mu \mathrm{l}$ of medium containing different concentrations of HP-1 
ethyl acetate extract $(25,50,100,200$ and $400 \mu \mathrm{g} / \mathrm{ml})$ and fumagillin control group $(100 \mu \mathrm{M})$ impedance monitoring continued for another $72 \mathrm{~h}$. Dose-response curves at $72 \mathrm{~h}$ were generated in order to determine $\mathrm{IC}_{50}$ values during the incubation time. The electrical impedance was analysed by the RTCA-connected software of the RTCA DP system as a dimensionless parameter called CI.

\section{Cell migration and invasion assays with real-time cell analysis system:}

Cell migration and invasion assays were conducted with RTCA DP by using CIM-16 plates that contains microelectronic sensors connected onto the underside of the plate ${ }^{[10]}$. For invasion assay, top part wells of the CIM-16 plate were coated with $20 \mu 1$ of $20 \%$ matrigel and incubated at $37^{\circ}, 5 \% \mathrm{CO}_{2}$ for $4 \mathrm{~h}$ before the experiment. And then for both migration and invasion assays, the wells of the bottom chamber were filled with $160 \mu \mathrm{l}$ of $10 \%$ serum containing growth F12K medium and the top and bottom parts of the CIM-16 plates were assembled together. After the addition of $20 \mu \mathrm{l}$ serum-free F12K medium to the top chamber wells, the assembled CIM-Plates 16 were allowed to stabilize for $1 \mathrm{~h}$ at the incubator. After the incubation, HUVEC cells were seeded at a $2 \times 104$ density per well onto the top chambers of CIM-16 plates in 80 $\mu \mathrm{l}$ of serum-free media, then $100 \mu \mathrm{l}$ of HP-1 extract concentrations $(25,50,200 \mu \mathrm{g} / \mathrm{ml})$ were added. After stabilizing CIM-plates for $30 \mathrm{~min}$ at room temperature, the chamber was loaded in the RTCA DP machine and software was set to collect impendence data, reported as CI values, once every $10 \min$ for $24 \mathrm{~h}^{[9,11]}$.

\section{Morphological migration analysis:}

Antimigratory effects of the extract on HUVEC cells were investigated by using The Oris ${ }^{\mathrm{TM}}$ Cell Migration Assay kit (Platypus Technologies, LLC., Madison, WI). Briefly, cells were collected in growth medium at $5 \times 10^{4}$ cells $/ \mathrm{ml}$ and, $100 \mu \mathrm{l}$ of the cell suspension was added to each well of the Oris plate. After $24 \mathrm{~h}$ incubation at $37^{\circ}$ in a $5 \% \mathrm{CO}_{2}$ incubator, the stoppers and then current medium were removed carefully from the Oris plate. A total of $100 \mu \mathrm{l}$ of $\mathrm{IC}_{50}$ concentration of the extract $(37,89 \mu \mathrm{g} / \mathrm{ml})$ and $0.1 \%$ DMSO containing control group were added to wells and incubated for another $24 \mathrm{~h}$. At the end of the incubation period each well was stained with $10 \mu \mathrm{l}$ blue fluorescent Hoechst 33258, for $5 \mathrm{~min}$ and images were captured and absorbance's were measured in cytation 3 cell imaging multi-mode reader (Bio-Tek) using the blue filter cube.
mRNA expression levels of angiogenesis-related genes:

For RNA isolation, Caco-2 and HUVEC cells were seeded at $5 \times 10^{5}$ density per well in growth medium on 6-well plate. After $24 \mathrm{~h}$, cells were treated with $\mathrm{IC}_{50}$ concentration of the extract $(3789 \mu \mathrm{g} / \mathrm{ml})$. After 24 $\mathrm{h}$, cells were scratched and total RNA isolation was conducted by following the Magna Pure Compact protocol for the Magna Pure Compact RNA Isolation Kit on Magna Pure LC 2.0 system. The high quality of the RNA samples was confirmed by using the NanoDrop Instrument at 260 and $280 \mathrm{~nm}$ optical densities. From each RNA population, $500 \mathrm{ng}$ total RNA was used for cDNA synthesis with the Transcriptor High Fidelity cDNA Synthesis Kit (Cat.No.:05091284001, Roche) and reverse transcription reactions were performed according to the kit procedure. The quality of the cDNA samples were also confirmed with the NanoDrop instrument.

The resulting total cDNA was used in quantitative real time-polymerase chain reaction (qRT-PCR) to measure angiogenesis related VEGFA, VEGFB, EGFR, COX-10, ANGPT-1 and IL-8 genes mRNA expression levels. The RT-PCR mixture contained 10 $\mu 12 X$ LightCycler $^{\circledR} 480$ Probes Master, $1 \mu$ of each primer (Roche RealTime Ready Focus Gene Panel for angiogenesis, Ref. no.: 05582610001) $4 \mu$ PCR grade water and $5 \mu \mathrm{l}$ of cDNA. The primer sequences and cycling conditions are shown in Tables 1 and 2 . The mRNA levels of glyceraldehyde 3-phosphate dehydrogenase (GAPDH) were used as internal positive control. A qPCR using the Universal ProbeLibrary detection format was performed on the LightCycler ${ }^{\circledR}$ 480 Instrument to quantify gene expression. Results were analysed by advanced relative quantification with the instrument's software 1.5.0 SP4 (version 1.5.0.39).

\section{Statistical analysis:}

Graphics were drawn with GraphPad Prism 6.0 software (GraphPad Software Inc., San Diego California USA) and statistically analysed with one way analysis of varience (ANOVA) and Tukey's post hoc test. Results are expressed as mean \pm standard deviation and the means of 3 independent experiments ( $n=8$ for WST$1 ; \mathrm{n}=3$ for morphological migration analysis), $\mathrm{P}<0.001$ was considered to be significant compared to control group.

\section{RESULTS AND DISCUSSION}

Cytotoxic effects of HP-1 extract on HUVEC and 


\begin{tabular}{lcc}
\hline Primer & \multicolumn{1}{c}{ Forward sequence } & Reverse sequence \\
\hline VEGFA & 5'-GCAAGACAAGAAAAATGTGACAA-3' & 5'-TGGTTTCTGTATCGATCGTTCT-3' \\
VEGFB & 5'-CTGGCCACCAGAGGAAAGT-3' & 5'-CATGAGCTCCACAGTCAAGG-3' \\
EGFR & 5'-CAGCCACCCATATGTACCATC-3' & 5'-AACTTTGGGCGACTATCTGC-3' \\
COX-10 & 5'-CGTAAATTATGGCCGCATCT-3' & 5'-GACAGAGCCTCCTACGCAAC-3' \\
ANGPT1 & 5'-AGCTACCACCAACAACAGTG-3' & 5'-CAAAGATTGACAAGGTTGTGG-3' \\
IL-8 & 5'-TAGCCAGGATCCACAAGTCC-3' & 5'-CTGTGAGGTAAGATGGTGGCTA-3' \\
GAPDH & 5'-CTCTGCTCCTCCTGTTCGAC-3' & 5'-ACGACCAAATCCGTTGACTC-3' \\
\hline
\end{tabular}

TABLE 2: RT-PCR CYCLING CONDITIONS

\begin{tabular}{lccc}
\hline & RT-PCR cycling conditions & \\
\hline Step & Heat & Duration & Cycle \\
\hline Incubation & $95^{\circ}$ & $10 \mathrm{~min}$ & 1 \\
Amplification & $95^{\circ}$ & $10 \mathrm{~s}$ & \\
& $60^{\circ}$ & $30 \mathrm{~s}$ & 45 \\
Cooling & $72^{\circ}$ & $1 \mathrm{~s}$ & 1 \\
\hline
\end{tabular}

Caco-2 cells, in order to evaluate the cytotoxic effects of the extract on HUVEC and Caco-2 cells, a WST1 assay was performed with different concentrations. As mentioned before, WST-1 is metabolized by cellular NAD-dependent dehydrogenase into the coloured product of WST-1, formazan. The amount of dye correlates with the number of viable cells. According to our results, both HUVEC and Caco2 cell viability were significantly decreased by HP-1 secondary metabolites $(\mathrm{P}<0.001$, fig. 1$)$. WST-1 results were used as a preliminary screening for RTCA-DP concentrations.

In order to evaluate the effects of HP-1 extract secondary metabolites on cell proliferation of HUVEC and Caco-2 cells and calculate $\mathrm{IC}_{50}$ concentrations for following experiments, cell proliferation analysis were conducted with RTCA DP system. According to our results, $\mathrm{IC}_{50}$ concentrations of HP-1 extract for Caco2 and HUVEC were calculated as 55.2 and $37.89 \mu \mathrm{g} /$ $\mathrm{ml}$ for $24 \mathrm{~h}$, respectively (figs. 2 and 3). In addition, fumagillin was used as positive control in order to compare the anticancer effect of the extract and we found that HP-1 extract decreased Caco-2 cell viability more than fumagillin concentration $(100 \mu \mathrm{M})$.

Endothelial cell migration and invasion are important steps of angiogenesis. In order to evaluate the effects of HP-1 extract secondary metabolites on angiogenesis, real-time cell migration and invasion assays were performed with RTCA DP system on HUVEC cells, The analysis was conducted with high $(200 \mu \mathrm{g} / \mathrm{ml})$, medium $(50 \mu \mathrm{g} / \mathrm{ml})$ and low $(25 \mu \mathrm{g} / \mathrm{ml})$ concentration range including $\mathrm{IC}_{50}$ value, which was predetermined $37.89 \mu \mathrm{g} / \mathrm{ml}$ (figs. 4 and 5). Both cell migration and invasion were decreased depending on the increasing concentrations of the extract. Especially, $200 \mu \mathrm{g} /$ $\mathrm{ml}$ extract concentration highly supressed migration and invasion. In parallel to RTCA-DP analysis and according to Oris ${ }^{\mathrm{TM}}$ cell migration result, HUVEC cell migration has decreased by $28.43 \%$ at $\mathrm{IC}_{50}$ extract concentration $(37.89 \mu \mathrm{g} / \mathrm{ml})$ compared to control (fig. 6).

Both HUVEC and Caco-2 cells were incubated with $\mathrm{IC}_{50}$ concentrations, $37.89 \mu \mathrm{g} / \mathrm{ml}$ and $55.2 \mu \mathrm{g} / \mathrm{ml}$ respectively, for $24 \mathrm{~h}$ and mRNA expression levels of angiogenesis and metastasis related VEGF A, VEGF B, EGFR, COX-10, ANGPT-1 and IL-8 genes were determined by qRT-PCR method. According to our results, expression levels decreased 39.53, 64.86, $48.16,51.65,80.56,78.40 \%$ for Caco-2 cells and $45.86,9.15,31.12,21.29,60.82,39.21 \%$ for HUVEC cells respectively (fig. 7).

Studies over the past 30 y have provided significant insights about angiogenic process and its role in cancer pathology; angiogenesis is a hallmark of cancer that enables tumour growth. Vascular endothelial growth factors are key players in the process of tumour angiogenesis, and the VEGF pathway has therefore been an important focus for anticancer drug development ${ }^{[12]}$. After the first VEGF-targeted agent, the antiVEGF monoclonal antibody bevacizumab (Avastin, Genentech), showing clinical benefit in patients with metastatic CRC when combined with chemotherapy, the studies about angiogenic process has continued to increase ${ }^{[13]}$. However, $40-60 \%$ of tumours progressed after initially successful treatment because of the development of resistance to antiangiogenic therapy, a state exhibiting a poor prognosis and 

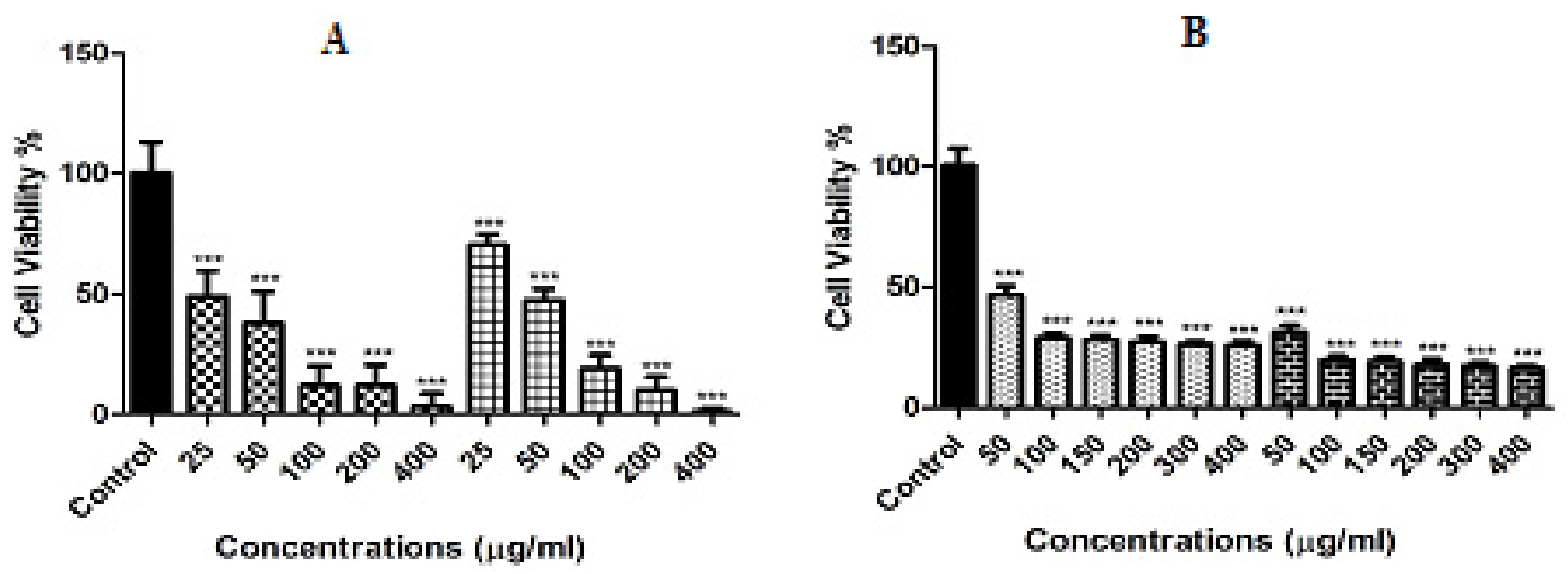

Fig. 1: Cytotoxic effects of HP-1 extract concentrations

HUVEC (A) and Caco-2 (B) cells were determined by WST-1 assay. HP-1 extract was inhibited cell viability depending on increasing concentrations (n=8, ***P<0.001). A- $24 \mathrm{~h}$;

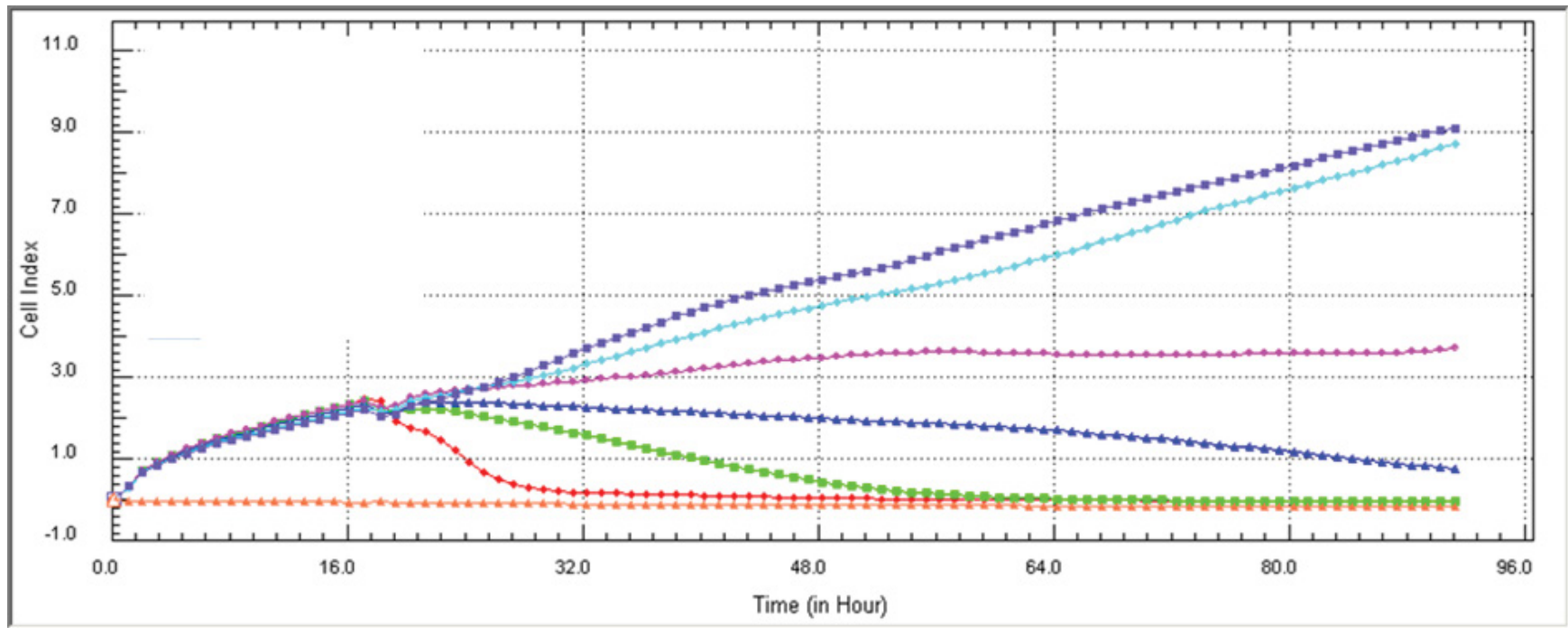

Fig. 2: Real-time monitoring of antiproliferative effects of HP-1 extract on HUVEC cell line

IC $_{50}: 37.89 \mu \mathrm{g} / \mathrm{ml}$ at $24 \mathrm{~h}$, results were obtained by using RTCA-DP system (n=8). $\bullet$ Control (0.1\% DMSO); $\bullet 25 \mu \mathrm{g} / \mathrm{ml} ; \bullet 50 \mu \mathrm{g} /$ $\mathrm{ml} ; \bullet 100 \mu \mathrm{g} / \mathrm{ml} ; \bullet 200 \mu \mathrm{g} / \mathrm{ml} ; \bullet 400 \mu \mathrm{g} / \mathrm{ml} ; \bullet$ medium

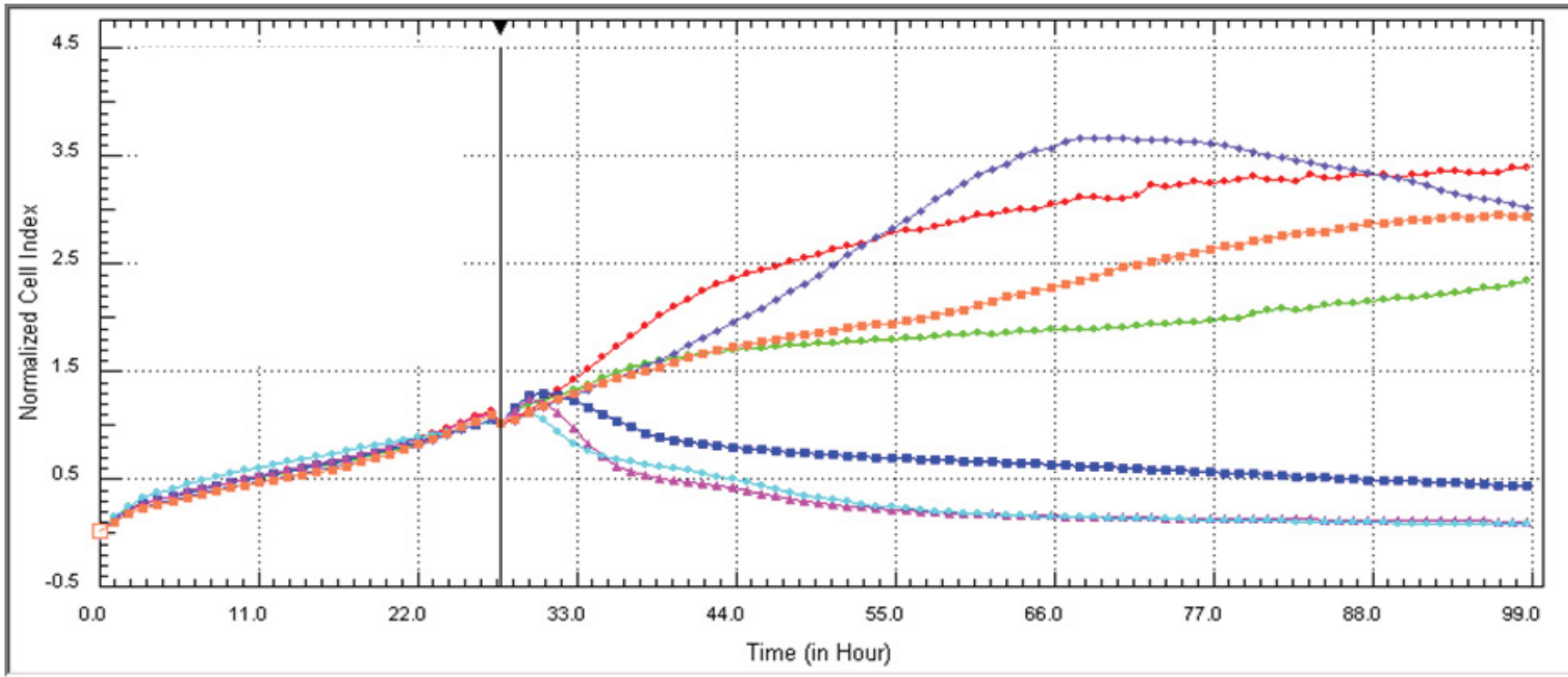

Fig. 3: Real-time monitoring of antiproliferative effects of HP-1 extract on Caco-2 cell line

$\mathrm{IC}_{50}: 55.2 \mu \mathrm{g} / \mathrm{ml}$ at $24 \mathrm{~h}$, results were obtained by using RTCA-DP system (n=8). $\bullet$ Control (0.1\% DMSO); $25 \mu \mathrm{g} / \mathrm{ml} ; \bullet 50 \mu \mathrm{g} / \mathrm{ml} ;$ $\bullet 100 \mu \mathrm{g} / \mathrm{ml} ; \bullet 150 \mu \mathrm{g} / \mathrm{ml} ; \bullet 200 \mu \mathrm{g} / \mathrm{ml}$; • fumagillin (100 $\mu \mathrm{M})$ 

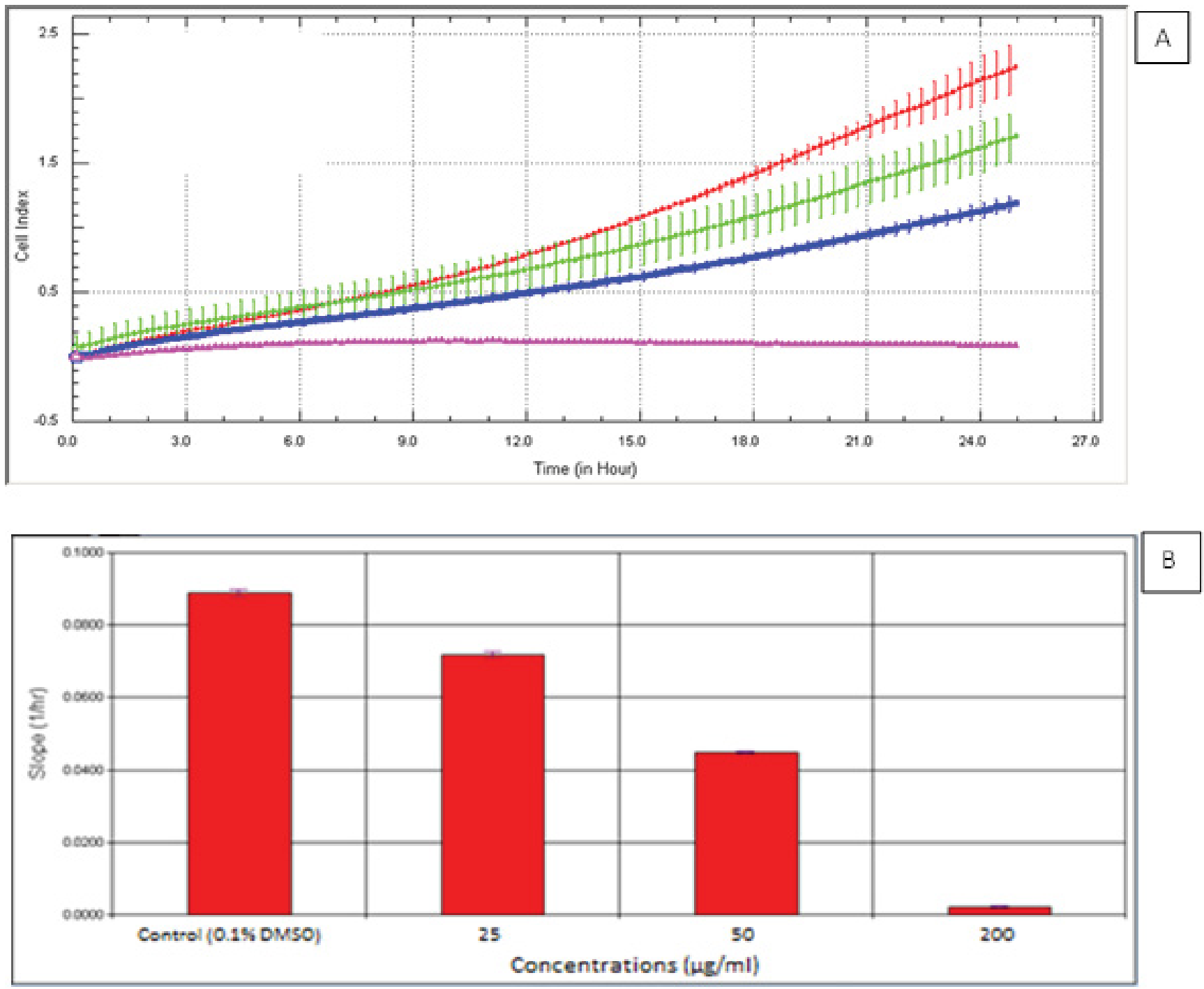

Fig. 4: Inhibitory effects of various concentrations of HP-1 extract

HUVEC cell migration (A), the slope of the migration curve was calculated using the RTCA 1.2.1 software (B). • Control (0.1\% DMSO); $\bullet 25 \mu \mathrm{g} / \mathrm{ml} ; \bullet 50 \mu \mathrm{g} / \mathrm{ml} ; \bullet 200 \mu \mathrm{g} / \mathrm{ml}$

response to available treatments ${ }^{[14]}$, with heightened invasiveness and in some cases increased lymphatic and distant metastasis ${ }^{[15]}$. Therefore, there is a need for new antiangiogenic and also antimetastatic compounds in CRC therapy.

Fungi represent a large group of eukaryotic organisms on earth and serve as biofactories for several bioactive compounds. Secondary metabolites are low-molecular weight bioactive natural products and essential for growth and survival functions of fungi ${ }^{[16]}$. Hyper saline environments originated by the evaporation of water and precipitation of the sodium chloride $(\mathrm{NaCl})$ eventually increases the salinity ${ }^{[17]}$. Fungi from hyper saline environments adapt to high salt condition with its antioxidant capacity ${ }^{[18]}$.

Largely, hyper saline fungal communities are dominated by Aspergillus and Penicillium species ${ }^{[19]}$.
In this study, we investigated the antimetastatic and antiangiogenic effects of halotolerant HP-1 extract secondary metabolites with high antioxidant capacity and isolated from Tuz Lake, a big salt lake in Turkey. Ethyl acetate extract showed significant cytotoxic and antiproliferative effects with $\mathrm{IC}_{50}$ concentrations $(55.2 \mu \mathrm{g} / \mathrm{ml}$ for Caco-2 and $37.89 \mu \mathrm{g} / \mathrm{ml}$ for HUVEC). Especially, HP-1 secondary metabolites decreased Caco-2 cell viability more than fumagillin, which is a potent fungal metabolite first isolated from Aspergillus fumigatus and widely used in a variety of microsporidian fungal infections and it has been researching for cancer treatments because of its angiogenesis inhibitory properties ${ }^{[20]}$. Antiangiogenic properties of the extract were demonstrated with HUVEC cell migration and invasion analysis, which resulted with significant decrease, especially at 50 and $200 \mu \mathrm{g} / \mathrm{ml}$ concentrations. 

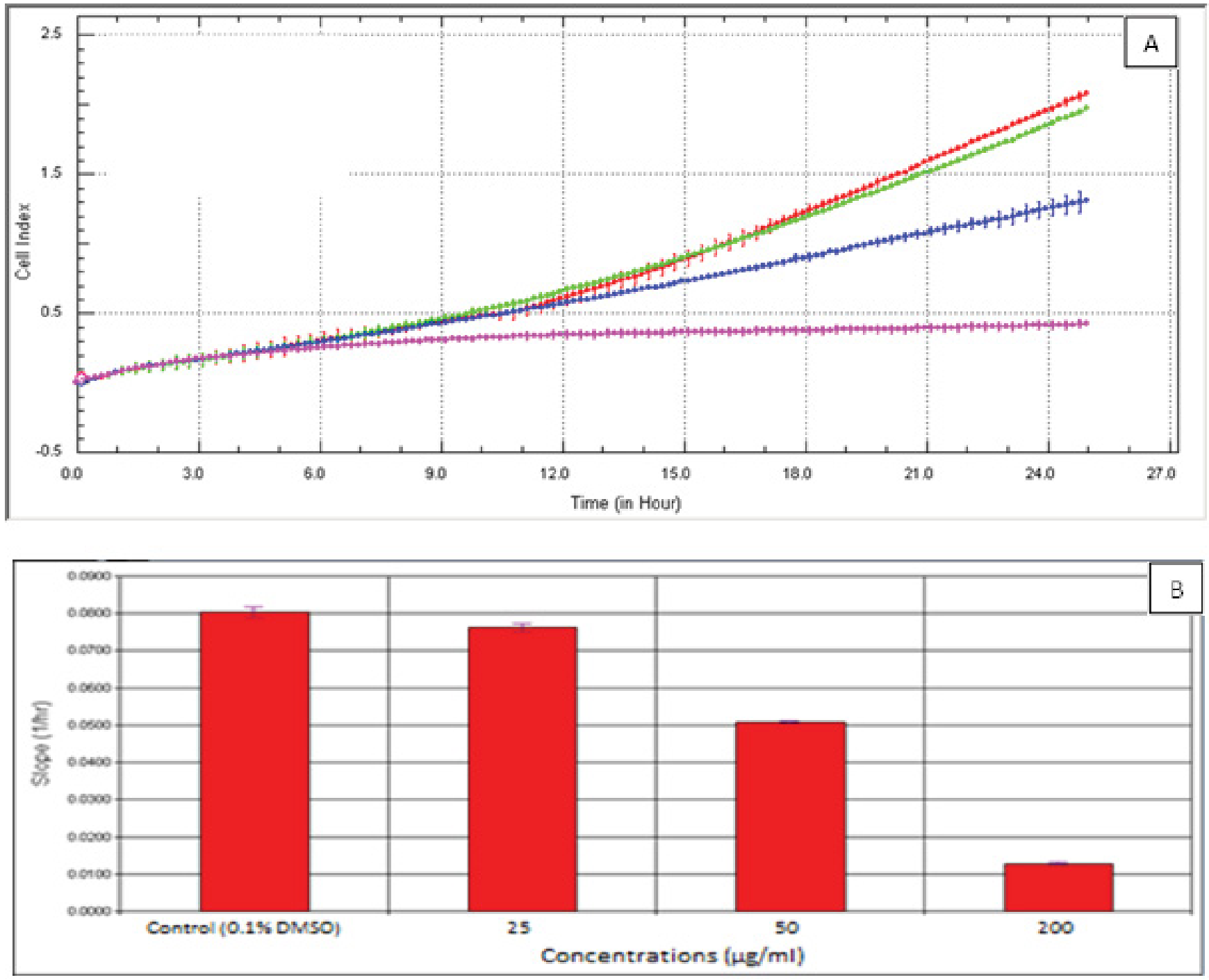

Fig. 5: Antiinvasive effects of various concentrations of HP-1 extract

HUVEC cells (A), the slope of the invasion curve was calculated using the RTCA 1.2.1 Software (B). $\bullet$ Control (0.1\% DMSO); $\bullet 25$ $\mu \mathrm{g} / \mathrm{ml} ; \bullet 50 \mu \mathrm{g} / \mathrm{ml} ; \bullet 200 \mu \mathrm{g} / \mathrm{ml}$

In this study, we determined that mRNA expression levels of VEGF A, VEGF B, EGFR, COX-10, ANGPT-1 and IL-8 genes were decreased both HUVEC and Caco-2 cells according to control. This result supported that HP-1 extract have important antimetastatic and antiangiogenic effects.

EGFR is a receptor of tyrosine kinase that plays a critical role in the survival, proliferation, migration, angiogenesis, and apoptosis, and EGFR signalling dysregulation results with overexpression, amplification, and mutation of the EGFR gene occurs frequently in several types of epithelial cancers, including colon cancer ${ }^{[21]}$. With other oncogenes, EGFR activating mutations can indirectly lead to an upregulation of VEGF expression ${ }^{[22]}$. IL-8 is a member of the CXC chemokine family and overexpression of IL-8 has been found to be a critical VEGF-independent mediator of tumour-associated angiogenesis ${ }^{[23]}$. The importance of cyclooxygenases in CRC development and progression led to many studies and many observational studies have reported a $40-50 \%$ relative risk reduction of developing colorectal adenomas and cancer, when comparing regular users of aspirin or non-steroidal antiinflammatory drugs to non-users ${ }^{[24]}$. Angiopoietins are a new family of growth factors that are specific for the vascular endothelium has been recently identified and responsible for vasculogenesis. Transgenic overexpression of angiopoietin-1 could lead to striking hyper vascularization. Angiopoietins are expressed simultaneously in carcinoma cells. Therefore, angiopoietins may promote the growth of tumours in an autocrine or paracrine fashion ${ }^{[25]}$.

In conclusion, this is the first evidence for the antiangiogenic effects on HUVEC cells and 

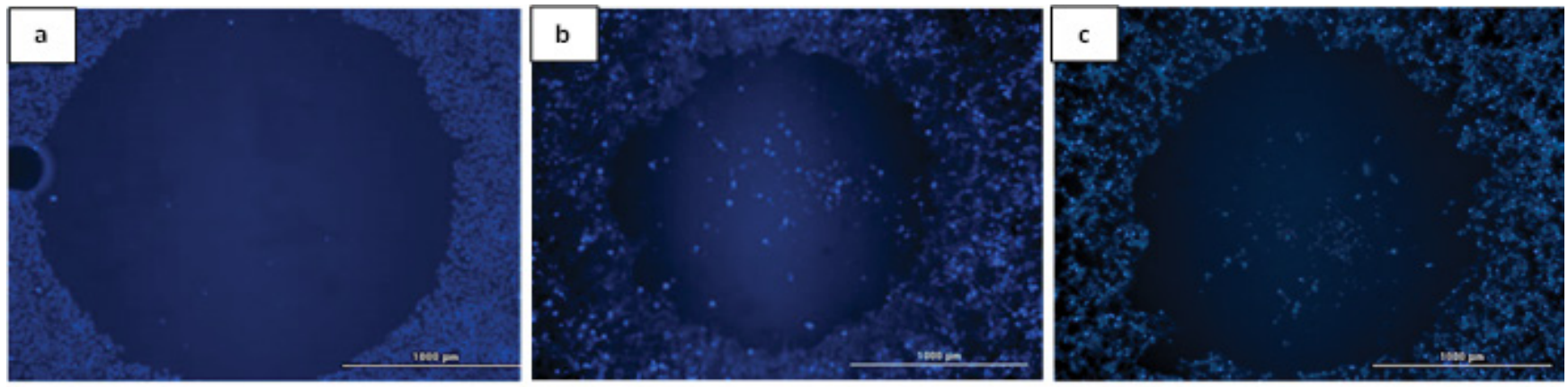

A

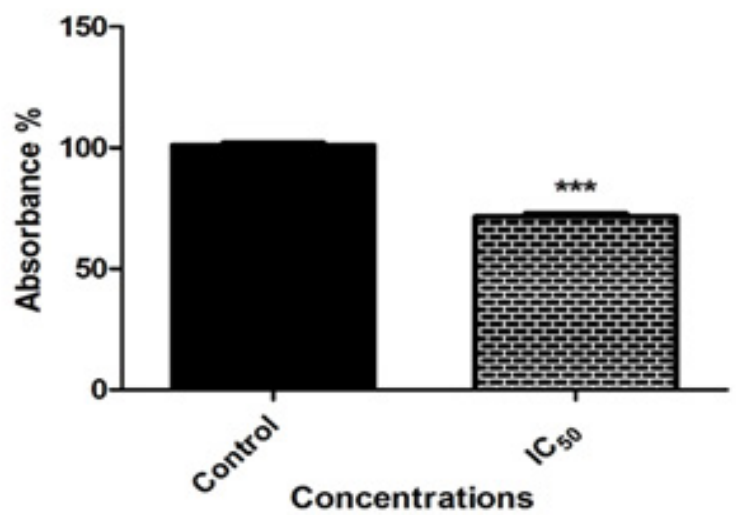

B

Fig. 6: Morphological migration analysis of HUVEC cells treated with HP-1 extract

A. HUVEC cells were treated with $\mathrm{IC}_{50}$ concentration $(37.89 \mu \mathrm{g} / \mathrm{ml})$ of $\mathrm{HP}-1$ extract for $24 \mathrm{~h}$ and stained with Hoechst 33258 . The image of the well at a) initiation, b) control group (0.1\% DMSO) well and c) $\mathrm{IC}_{50}$ concentration treated well after $24 \mathrm{~h}$. B. Mean absorbance \% graph according to the control group. $(\mathrm{n}=3$, mean $\pm \mathrm{SD}, * * * \mathbf{P}<0.001)$

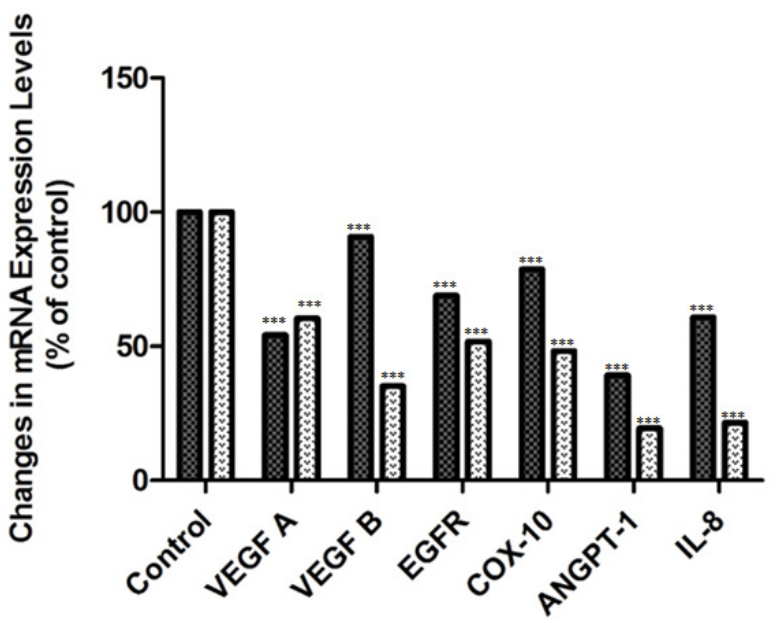

Fig. 7: Changes in the mRNA expression levels of angiogenesis related genes

Cells were treated with $\mathrm{IC}_{50}$ concentrations of HP-1 extract $(37.89 \mu \mathrm{g} / \mathrm{ml}$ for HUVEC and $55.2 \mu \mathrm{g} / \mathrm{ml}$ for Caco-2) for 24 h. Results were expressed as \% of the control group and the decrease in gene expression levels were found statistically significant according to the control group of each cell line $(* * * \mathbf{P}<0.001)$.

antimetastatic effects on Caco-2 cells of the HP-1 secondary metabolites isolated from Tuz Lake. These findings suggest that HP-1 secondary metabolites down regulated the mRNA expression levels of VEGF A, VEGF B, EGFR, COX-10, ANGPT-1 and IL-8, which are both angiogenesis and metastasis related genes based on the potential contribution of the antioxidant activity provided by the phenolic component of the extract. Secondary metabolites of halotolerant fungi, an excellent potential source of new natural products isolated from extreme environments like Tuz Lake may have potential in new drug development. Therefore, with further investigations on the active substance of the HP-1 extract, it might have an important role as a chemoprotective and antiangiogenic agent in the future.

\section{Acknowledgements:}

This research was carried supported by Anadolu University Scientific Research Project Unit (Number of project: 1003S117).

\section{Conflict of interest:}

There are no conflicts of interest. 


\section{Financial support and sponsorship:}

Nil.

\section{REFERENCES}

1. Rama AR, Aguilera A, Melguizo C, Caba O, Prados J. Tissue Specific Promoters in Colorectal Cancer. Dis Markers 2015;2015:390161.

2. Hassan LE, Ahamed MB, Majid AS, Baharetha H, Muslim NS, Nassar ZD, et al. Correlation of antiangiogenic, antioxidant and cytotoxic activities of some Sudanese medicinal plants with phenolic and flavonoid contents. BMC Complement Altern Med 2014;14:406.

3. Wang YT, Xue YR, Liu CH. A brief review of bioactive metabolites derived from deep-sea fungi. Mar drugs 2015; 13:4594-616.

4. Chávez R, Fierro F, García-Rico RO, Vaca I. Filamentous fungi from extreme environments as a promising source of novel bioactive secondary metabolites. Front Microbiol 2015;9:903.

5. Jenifer JS, Donio MB, Michaelbabu M, Vincent SG, Citarasu T. Haloalkaliphilic Streptomyces spp. AJ8 isolated from solar salt works and its' pharmacological potential. AMB Express $2015 ; 5: 142$.

6. Güven K, Mutlu MB, Çırpan C, Kutlu HM. Isolation and identification of selenite reducing archaea from Tuz (salt) Lake in Turkey. J Basic Microbiol 2013;53:397-401.

7. Pitt J. A Laboratory Guide to Common Penicillium Species. Food Science 2000;197.

8. Yang H, Liu C, Yang D, Zhang H, Xi Z. Comparative study of cytotoxicity, oxidative stress and genotoxicity induced by four typical nanomaterials: the role of particle size, shape and composition. J Appl Toxicol 2009;29:69-78.

9. Bird C, Kirstein S. Real-time, label-free monitoring of cellular invasion and migration with the xCELLigence system. Nature Methods 2009;6.

10. Limame R, Wouters A, Pauwels B, Fransen E, Peeters M, Lardon $\mathrm{F}$, et al. Comparative Analysis of Dynamic Cell Viability, Migration and Invasion Assessments by Novel Real-Time Technology and Classic Endpoint Assays. PLoS One 2012;7: e46536.

11. Eisenberg MC, Yangjin K, Li R, Ackerman WE, Kniss DA, Friedman A. Mechanistic modelling of the effects of myoferlin on tumor cell invasion. PLoS One 1998;108:20078-83.

12. Arjaans M, Schröder CP, Oosting SF, Dafni U, Kleibeuker JE, de Vries EG. VEGF pathway targeting agents, vessel normalization and tumor drug uptake: from bench to bedside. Oncotarget 2016;19:21247-58.
13. Ellis LM, Hicklin DJ. VEGF-targeted therapy: mechanisms of antitumour activity. Nature Rev Cancer 2008;8:579-91.

14. Hu YL, Jahangiri A, DeLay M, Aghi MK. Tumor cell autophagy as an adaptive response mediating resistance to treatments such as antiangiogenic therapy. Cancer Res 2012;72:4294-9.

15. Pàez-Ribes M, Allen E, Hudock J, Takeda T, Okuyama H, Viñals F, et al. Antiangiogenic therapy elicits malignant progression of tumors to increased local invasion and distant metastasis. Cancer Cell 2009;15:220-31.

16. Demain AL. Regulation of secondary metabolism in fungi. Pure Appl Chem 1986;58:219-26.

17. Oren A. Diversity of halophilic microorganisms: environments, phylogeny, physiology, and applications. J Ind Microbiol Biotechnol 2002;28:56-63.

18. Ravindran C, Varatharajan GR, Rajasabapathy R, Vijayakanth $\mathrm{S}$, Kumar AH, Meena RM. A role for antioxidants in acclimation of marine derived pathogenic fungus (NIOCC 1) to salt stress. Microb Pathog 2012;53:168-79.

19. Leitão AL, García-Estrada C, Ullán RV, Guedes SF, MartínJiménez P, Mendes B, et al. Penicillium chrysogenum Var. halophenolicum, a new halotolerant strain with potential in the remediation of aromatic compounds in high salt environments. Microbiol Res 2012;167:79-89.

20. Van den Heever JP, Thompson TS, Curtis JM, Ibrahim A, Pernal SF. Fumagillin: an overview of recent scientific advances and their significance for apiculture. J Agric Food Chem 2014;62:2728-37.

21. Wang J, Du Y, Liu X, Cho WC, Yang, Y. MicroRNAs as regulator of signaling networks in metastatic colon cancer. Biomed Res Int 2015:823620.

22. Pore N, Jiang Z, Gupta A, Cerniglia G, Kao GD, Maity A. EGFR tyrosine kinase inhibitors decrease VEGF expression by both hypoxia-inducible factor (HIF)-1-independent and HIF-1-dependent mechanisms. Cancer Res 2006;66:3197-204.

23. Lurje G, Zhang W, Schultheis AM, Yang D, Groshen S, Hendifar AE, et al. Polymorphisms in VEGF and IL-8 predict tumor recurrence in stage III colon cancer. Ann Oncol 2008;19:1734-41.

24. Omura N, Griffith M, Vincent A, Li A, Hong SM, Walter $\mathrm{K}$, et al. Cyclooxygenase-deficient pancreatic cancer cells use exogenous sources of prostaglandins. Mol Cancer Res 2010;8:821-32.

25. Nakayama T, Hatachi G, Wen CY, Yoshizaki A, Yamazumi $\mathrm{K}$ Niino $\mathrm{D}$, et al. SekineExpression and significance of Tie- 1 and Tie-2 receptors, and angiopoietins-1, 2 and 4 in colorectal adenocarcinoma: Immunohistochemical analysis and correlation with clinicopathological factors. World J Gastroenterol 2005;11:964-9. 